\title{
OVERVIEW OF THE ROLE-PLAYERS IN THE INVESTIGATION, PREVENTION AND ENFORCEMENT OF MARKET-ABUSE PROVISIONS IN SOUTH AFRICA*
}

\author{
Howard Chitimira \\ LLB LLM LLD \\ Lecturer, Faculty of Law \\ North-West University, Mafikeng \\ Vivienne A Lawack \\ BJuris LLB LLM LLD \\ Professor of Law, Executive Dean, Faculty of Law \\ Nelson Mandela Metropolitan University \\ Port Elizabeth
}

\section{SUMMARY}

This article analyses the role and effectiveness of selected key role-players primarily dealing with the investigation, prevention and enforcement of the market abuse prohibition in South Africa in order to increase awareness on the part of the general public, policy-makers and other relevant stakeholders. To this end, the article provides an overview analysis of selected role-players as well as their distinct functions in the investigation, prevention and combating of market-abuse practices in South Africa. This is done by discussing the roles of the Financial Services Board, the Directorate of Market Abuse and the Enforcement Committee.

Key Terms: insider trading, market abuse, Enforcement Committee, JSE, Board of Appeal, Financial Services Board, Directorate of Market Abuse, financial markets, market manipulation, role-players.

\section{INTRODUCTION}

The objective of this article is to analyse the role and effectiveness of selected key role-players who primarily deal with the investigation, prevention and enforcement of the market-abuse prohibition in South Africa in order to increase awareness on the part of the general public, policymakers and other relevant stakeholders. Put differently, this article examines whether the relevant market-abuse provisions are being effectively implemented by the role-players to prevent insider trading and market manipulation in the South African financial markets. To this end, the article 
provides an overview analysis of selected role-players as well as their distinct functions in the investigation, prevention and combating of marketabuse practices in South Africa. This is done by discussing the roles of the Financial Services Board, the Directorate of Market Abuse and the Enforcement Committee. Consequently, other role-players who primarily deal with the detection of market-abuse cases and the enforcement of appeals involving such cases in South Africa, namely, the Board of Appeal, the Johannesburg Stock Exchange Limited ${ }^{1}$ and the courts will not be discussed in this article.

\section{THE INVESTIGATION, PREVENTION AND ENFORCEMENT OF THE MARKET-ABUSE PROHIBITION IN SOUTH AFRICA}

\section{The role of the Financial Services Board}

The Financial Services Board is an independent board established ${ }^{2}$ inter alia to monitor and enforce the market-abuse prohibition in South Africa. Accordingly, the functions of the Financial Services Board under the Financial Services Board Act include:

(a) supervising compliance with laws regulating financial institutions ${ }^{3}$ and the provision of financial services; ${ }^{4}$

(b) advising the Minister on matters concerning financial institutions and financial services, either of its own accord or at the request of the Minister, ${ }^{5}$ and

(c) promoting programmes and initiatives by financial institutions and bodies representing the financial services industry to inform and educate users and potential users of financial products and services. ${ }^{6}$

Moreover, the Financial Services Board was given ostensibly wide powers to ensure the proper supervision and enforcement of the South African market-abuse prohibition in terms of the Securities Services Act. ${ }^{7}$ For instance, the Financial Services Board had powers which include to:

(a) supervise and to ensure that all persons comply with the market-abuse provisions; ${ }^{8}$

* This article was influenced in part, by Chitimira's doctoral thesis entitled $A$ Comparative Analysis of the Enforcement of Market-Abuse Provisions (2012) LLD Thesis, Nelson Mandela Metropolitan University (see Chapter 3). In this regard, he wishes to acknowledge the expert help and input of Professor Lawack.

Hereinafter "the JSE".

2 S 2 of the Financial Services Board Act 97 of 1990 (hereinafter "the Financial Services Board Act").

See the definition of the term "financial institution" in $\mathrm{s} 1$ of the Financial Services Board Act.

S 3(a) of the Financial Services Board Act.

S 3(b) of the Financial Services Board Act.

S 3(c) of the Financial Services Board Act.

36 of 2004, hereinafter "the Securities Services Act"; and see s 82 of the Securities Services Act.

8 S 82(1) of the Securities Services Act. 
(b) investigate any matter relating to an offence relating to market abuse, including insider trading committed before the repeal of the provisions of the Insider Trading Act and section 440F of the Companies Act; ${ }^{9}$

(c) institute proceedings as are contemplated in terms of the relevant market-abuse provisions; ${ }^{10}$

(d) administer proof of claims and distribution of payments in civil cases of insider trading; ${ }^{11}$

(e) summon any person suspected to be in possession of any information or document relevant to an ongoing investigation of the Financial Services Board for interrogation or production of such document; ${ }^{12}$

(f) interrogate any such persons under oath or affirmation and examine or retain for further examination any such document unless the copies of any such document have been made $;^{13}$

(g) enter and search, after obtaining a search warrant, any premises or open any strongroom for the purpose of obtaining any document which it suspects might relate to an ongoing investigation and, if found, to examine, make extracts from and copy the document or remove it temporarily from those premises for that purpose or retain it for as long as it may be required for criminal or other proceedings; ${ }^{14}$

(h) make market-abuse rules after consultation with the Directorate of Market Abuse $;{ }^{15}$ require relevant regulated markets to implement such systems as are necessary for the effective monitoring and identification of market-abuse activities. This is done after consultation with such markets; ${ }^{16}$

(i) delegate, subject to conditions it may determine, the power to investigate, interrogate or search premises or persons accused of violating the market-abuse provisions to any fit person; ${ }^{17}$

(j) publish in the Gazette a notice of any proposed market-abuse rule or amendment of such rule and to call all interested persons who have objections to the proposed rule or amendment to lodge their objections with the Financial Services Board within a period of fourteen days from the date of publication of the notice, ${ }^{18}$

(k) ensure, after consultation with the Directorate of Market Abuse, that the market-abuse rule or amendment to such rule comes into operation on a

\footnotetext{
S 82(2)(a) of the Securities Services Act.

$S$ 82(2)(b) of the Securities Services Act.

$S$ 82(2)(c) of the Securities Services Act.

$S$ 82(2)(d) of the Securities Services Act.

$\mathrm{S} 82(2)(\mathrm{e})$ of the Securities Services Act.

$\mathrm{S} 82(2)(f)$ read with sub-section (3) of the Securities Services Act.

$\mathrm{S} 82(2)(\mathrm{g})$ of the Securities Services Act.

$\mathrm{S}$ 82(2)(h) of the Securities Services Act.

S 82(4) of the Securities Services Act.

S 82(5) of the Securities Services Act.
} 
date determined by the Financial Services Board by notice in the Gazette if there were no objections; ${ }^{19}$

(I) amend the proposed market-abuse rule after consultation with the Directorate of Market Abuse and ensure that the amended rule comes into operation on a date determined by the Financial Services Board by notice in the Gazette and ensure that such rule is binding on regulated persons and members of the public; ${ }^{20}$

(m) prosecute any alleged market-abuse offence in any competent court ${ }^{21}$ if the Director of Public Prosecutions declines to do so, in terms of the Securities Services Act and the Criminal Procedure Act; $; 2$ and

(n) investigate any matter, summon and interrogate any person in respect of matters relating to market abuse at the request of the Directorate of Market Abuse.

As indicated above, these wide powers are relatively similar to the duties that were initially conferred upon the Financial Services Board under the Insider Trading Act. ${ }^{24}$ Over and above, the same powers were retained with a few minor changes in the Financial Markets Bill 2011, ${ }^{25}$ the Financial Markets Bill $2012^{26}$ and the Financial Markets Act. ${ }^{27}$ In relation to this, such changes include new powers that are conferred upon the Financial Services Board to:

(a) assist foreign regulators with investigations pertaining to any crossborder market-abuse cases; ${ }^{28}$

(b) publish by notice on its official website or by means of other appropriate public media, any outcome, status or details of market abuse investigations (public censure) if such publication is in the public interest; ${ }^{29}$ and

(c) enter upon or search any premises in relation to market-abuse investigations during the day and ensure that such investigations could be assisted by a police officer, in a orderly justifiable manner with due

\footnotetext{
S 82(6) of the Securities Services Act.

S 82(7) and (8) of the Securities Services Act.

S 79 of the Securities Services Act.

2251 of 1977. See s 82(9) of the Securities Services Act; also see s 8(2) and (3) of the Criminal Procedure Act 51 of 1977.

23 S 82(10) of the Securities Services Act.

24135 of 1998, hereinafter "the Insider Trading Act"; and see s 11 of the Insider Trading Act.

25 Clause 91 of the Financial Markets Bill [B-2011], hereinafter "the Financial Markets Bill".

26 Clause 86 of the Financial Markets Bill [B12-2012], hereinafter "the Financial Markets Bill 2012" (for the purposes of this article, the term "clause" is employed to refer to the provisions of both the Financial Markets Bill and the Financial Markets Bill 2012).

2719 of 2012, hereinafter "the Financial Markets Act"; and see s 84 of the Financial Markets Act.

28 Clause 91(2)(b) of the Financial Markets Bill; clause 86(2)(b) of the Financial Markets Bill 2012; and s 84(2)(b) of the Financial Markets Act.

29 Clause $91(2)(\mathrm{e})$ of the Financial Markets Bill; clause 86(2)(e) of the Financial Markets Bill 2012; and s 84(2)(e) of the Financial Markets Act.
} 
regard to the accused person's right to dignity, privacy, freedom and security. ${ }^{30}$

Nonetheless, it remains to be seen whether the Financial Services Board will be able to enforce its public censure and other investigation powers introduced by the Financial Markets Bill consistently and timeously. The Financial Markets Bill 2012 and the Financial Markets Act were to combat market-abuse activities in South Africa and elsewhere.

The Financial Services Board is staffed with persons who have forensic and prosecutorial skills as well as relevant expertise in relation to the financial markets. Despite this, the Financial Services Board does not have its own sophisticated surveillance equipment in place to detect any suspected illegal trading and to provide the details of the beneficial owners of securities held in nominee accounts. ${ }^{31}$ In most instances, the Financial Services Board relies on the JSE's Surveillance Division to detect suspicious trading volumes and trading patterns. The Financial Services Board further relies on the broker-dealer accounts system to extract relevant information from other market participants like brokers by investigating their trading history for purposes of detecting market-abuse practices. ${ }^{32}$ This enables the Financial Services Board to check a broker's trading history by scrutinizing his telephonic conversations, bank records and other relevant trading records to detect unusual or abnormal trading patterns which could be a signal of market-abuse activity. The Financial Services Board also uses the auction-process system to curb market manipulation. The Financial Services Board may investigate all the transactions that are carried out at the JSE by examining volumes of securities traded, say at the close of the day. Such transactions are kept in a database for easy identification and detection of illicit trading activities which may give rise to market abuse. This is referred to as the transactions-database system, which is reportedly being used by the Financial Services Board in some instances. ${ }^{33}$ Additionally, the Financial Services Board may publish or issue a press release to disclose the details of the proposed market-abuse rules regarding the affected securities and the culprits involved. ${ }^{34}$ This name and shaming practice is used by the Financial Services Board to deter persons from engaging in market-abuse activities because of fear of losing their jobs and damaging their reputation. ${ }^{35}$

In order to curb cross-border market-abuse activities, the Financial Services Board has forged some multilateral co-operation agreements with similar authorities in the developed world, like the Financial Services Authority of the United Kingdom and the Securities and Exchange

30 Clause 91(3)(g), (h) and (i) of the Financial Markets Bill; clause $86(4)(d)$, (e) and (f) of the Financial Markets Bill 2012; and s 84(4)(d), (e) and (f) of the Financial Markets Act.

31 Barrow "Insider Trading Directorate" 28 July 2004 Business Report.

32 This information was obtained from an interview that was conducted at the Financial Services Board by Howard Chitimira, with Mr Gerhard van Deventer (the Executive Director of the Directorate of Market Abuse or the DMA) on 05 May 2009.

33 Ibid.

34 S 82(5) to (8) of the Securities Services Act; also see clause 91(5) to (8) of the Financial Markets Bill; clause 86(6) to (9) of the Financial Markets Bill 2012; and s 84(6) to (9) of the Financial Markets Act.

35 Ibid. 
Commission of the United States of America. ${ }^{36}$ For example, if a South African citizen who is an insider but is domiciled in New York contacted a broker in South Africa to purchase any security listed on the JSE in order to conceal the illegal nature of such dealing, the Financial Services Board can rely on the United States Securities and Exchange Commission to investigate, interrogate or prosecute such person for market abuse. Van Deventer $^{37}$ submits that these multilateral co-operation agreements have been utilized by the Financial Services Board in a number of instances to combat cross-border market abuse.

The Financial Services Board may itself prosecute matters relating to market-abuse practices only when the relevant courts decline to do so ${ }^{38}$ or where a matter is settled out of court. The same authority is also retained in the Financial Markets Bill, the Financial Markets Bill 2012 and the Financial Markets Act. ${ }^{39}$ Moreover, a civil penalty for the actual profit made or loss avoided in matters relating to insider trading is determined by competent courts. ${ }^{40}$ Under the Financial Markets Bill, a similar civil penalty as determined by competent courts ${ }^{41}$ was extended to matters involving both insider trading ${ }^{42}$ and market manipulation. ${ }^{43}$ However, there is no provision for civil penalties for market manipulation under the Financial Markets Bill 2012 and the Financial Markets Act. ${ }^{44}$

Interrogation of persons or search of premises in matters relating to market abuse is only possible when permission or a search warrant is granted upon the application by the Financial Services Board, to a judge or magistrate who has jurisdiction in the area where the persons or premises are located. ${ }^{45}$ This could imply, given the backlog challenges in the South African courts, that not all premises and persons will be promptly searched, interrogated or prosecuted respectively by the Financial Services Board and the competent courts.

The Financial Services Board may only consult with, and request the regulated markets to have systems that are necessary to monitor and detect

36 See further Loubser "Insider Trading and other Market Abuses (Including the Effective Management of Price-sensitive Information)" 2 October 2006 Insider Trading Booklet final draft 2006 26-27 http://www.jse.co.za/public/insider/JSEbooklet.pdf (accessed 2008-10-10).

37 This information was obtained from an interview that was conducted at the Financial Services Board by Howard Chitimira, with Mr Gerhard van Deventer (the Executive Director of the DMA) on 05 May 2009.

S 82(9) of the Securities Services Act.

39 Clause 91(9) of the Financial Markets Bill; clause 86(10) of the Financial Markets Bill 2012; and s 84(10) of the Financial Markets Act respectively.

40 S 77 read with s 79 of the Securities Services Act.

41 See the definition of "court of competent jurisdiction" in s 81 of the Financial Markets Bill.

42 Clause 86 of the Financial Markets Bill.

43 Clause 87 of the Financial Markets Bill.

44 See clauses 82, 83 and other relevant clauses under Chapter X entitled "Market Abuse" of the Financial Markets Bill 2012; and s 80, s 81 and other relevant provisions under Chapter $\mathrm{X}$ entitled "Market Abuse" of the Financial Markets Act respectively.

$45 \mathrm{~S}$ 82(3)(a) of the Securities Services Act; also see clause 91(3)(e) of the Financial Markets Bill; clause $86(4)(b)$ of the Financial Markets Bill 2012; and s 84(4)(b) of the Financial Markets Act. Also see Crotty "First Insider Trading Case Goes to Court" 19 October 2001 Business Report; Cokayne "Setback for South Africa's First Insider Trading Case" 28 April 2004 Business Report. 
market-abuse practices in such markets. ${ }^{46}$ The same position is also retained in the Financial Markets Bill, the Financial Markets Bill 2012 and the Financial Markets Act. ${ }^{47}$ This may suggest that there is some co-operation between the Financial Services Board and the regulated markets in South Africa. Although more can still be done, one can argue that the Financial Services Board has so far played an important role in the detection, investigation and prevention of market abuse in South Africa. ${ }^{48}$

\section{The role of the Directorate of Market Abuse}

The Directorate of Market Abuse is established as a committee of the Financial Services Board which may perform some of its functions. ${ }^{49}$ Apart from the changing of the name from the Insider Trading Directorate to the Directorate of Market Abuse, ${ }^{50}$ the functions of the Directorate of Market Abuse under the Securities Services Act, ${ }^{51}$ the Financial Markets Bill, ${ }^{52}$ the Financial Markets Bill $2012^{53}$ and the Financial Markets Act ${ }^{54}$ still resemble those of the Insider Trading Directorate in many respects. ${ }^{55}$

Specifically, the Directorate of Market Abuse is made up of representatives of the regulated markets, the Share Holders' Association of South Africa, the fund-management industry, the insurance industry, the South African Reserve Bank, the bankers, and the accounting and legal professions. These persons are appointed by the Minister of Finance ${ }^{56}$ on the basis of their availability, expertise and knowledge of the financial markets. ${ }^{57}$ The same position is replicated in the Financial Markets Bill, the Financial Markets Bill 2012 and the Financial Markets Act without any major changes. $^{58}$

The Directorate of Market Abuse is empowered to institute any civil proceedings as contemplated in the Securities Services Act and to

$46 \mathrm{~S} 82(2)(\mathrm{h})$ of the Securities Services Act.

47 Clause $91(2)(\mathrm{g})$ of the Financial Markets Bill; clause $86(2)(\mathrm{g})$ of the Financial Markets Bill 2012; and s 84(2) $(\mathrm{g})$ of the Financial Markets Act respectively.

48 For further comparative discussion on the role of the Financial Services Board see Myburgh and Davis "The Impact of South Africa's Insider Trading Regime: A Report for the Financial Services Board" (25-03-2004) 15-30 http://www.genesis-analytics.com/public/FSBReport. pdf (accessed 09-02-2009).

$49 \mathrm{~S} 83(1)(\mathrm{a})$ of the Securities Services Act; also see clause 92(1)(a) of the Financial Markets Bill; clause 87(1)(a) of the Financial Markets Bill 2012; and $s$ 85(1)(a) of the Financial Markets Act.

50 S 83(1)(b) of the Securities Services Act; clause 92(1)(b) of the Financial Markets Bill; clause 87(1)(b) of the Financial Markets Bill 2012; and 85(1)(b) of the Financial Markets Act.

51 S 83(1)(c), (d) and (e).

52 Clause 92(1)(c), (d) and (e).

53 Clause $87(1)(c)$ and (d).

$54 \mathrm{~S} 85(1)(\mathrm{c})$ and $(\mathrm{d})$.

$55 \mathrm{~S} 12$ of the Insider Trading Act.

56 S 83(3)(a) to (j) of the Securities Services Act.

57 83(4) of the Securities Services Act.

58 Clause 92(3)(a) to (j) read with clause 92(4) of the Financial Markets Bill; clause 87(3)(a) to (j) read with clause 87(4) of the Financial Markets Bill 2012; and s 85(3)(a) to (j) read with s 85(4) of the Financial Markets Act respectively. 
investigate any matter relating to market abuse. ${ }^{59}$ If it obtains an appropriate warrant, it has the powers to summon, interrogate, and search and seize any documents in possession of suspected persons. ${ }^{60}$ These powers are also replicated in the Financial Markets Bill, the Financial Markets Bill 2012 and the Financial Markets Act. ${ }^{61}$ Moreover, the Directorate of Market Abuse may withdraw, abandon or compromise any civil proceedings instituted as contemplated in the Securities Services Act. ${ }^{62}$ Notably, in terms of the Financial Markets Bill, the Directorate of Market Abuse may withdraw, abandon or compromise any civil proceedings in respect of both insider trading and market manipulation. ${ }^{63}$ Nevertheless, any such compromise should be done in terms of an order of court and any compensatory amount recovered in terms of the compromise must be made public under the Securities Services Act ${ }^{64}$ as well as the Financial Markets Bill. ${ }^{65}$ No similar provision is made in the Financial Markets Bill 2012 and the Financial Markets Act. ${ }^{66}$

Furthermore, the Directorate of Market Abuse may, on behalf of the Financial Services Board, decide whether to refer a matter to the Enforcement Committee or to institute derivative civil proceedings or to refer a matter to the Director of Public Prosecutions ${ }^{67}$ In addition, the Directorate of Market Abuse may only institute civil proceedings in the name of the Financial Services Board and may settle any matter only after confirmation from the Financial Services Board or a competent court. This may rather indicate that the Directorate of Market Abuse exercises only certain specific powers in the name of the Financial Services Board. ${ }^{68}$

Although the referral of market-abuse cases to the Enforcement Committee does not affect the power of the Directorate of Market Abuse to take a derivative civil action against a person who contravenes the insidertrading provisions, ${ }^{69}$ no civil proceedings may be instituted in respect of the same set of facts if such person (respondent) has paid the compensatory amount as stipulated in the Securities Services Act. ${ }^{76}$ This is probably good and justifiable in that it is aimed at reducing the potentially negative affects of over-deterrence and the risk of double jeopardy on the part of the defendant concerned. Strikingly, no similar provision is contained in the Financial

\footnotetext{
$S$ 83(1)(c) of the Securities Services Act.

S 83(1)(c) read with s 82(2) of the Securities Services Act.

61 Clause 92(1)(c) of the Financial Markets Bill; clause 87(1)(c) of the Financial Markets Bill 2012; and s 85(1)(c) of the Financial Markets Act.

$62 \mathrm{~S} 78(1)$ of the Securities Services Act.

Clause 88(1).

$S 78(1)$ and (2) of the Securities Services Act.

Clause 88(1) and (2).

66 See the relevant clauses under Chapter X entitled "Market Abuse" of the Financial Markets Bill 2012 and relevant provisions under Chapter X entitled "Market Abuse" of the Financial Markets Act.

67 Loubser 2 October 2006 Insider Trading Booklet final draft 2006 26-27 http://www. jse.co.za/public/insider/JSEbooklet.pdf (accessed 2008-10-10).

68 Loubser 2 October 2006 Insider Trading Booklet final draft 200626 http://www.jse.co.za/ public/insider/JSEbooklet.pdf (accessed 2008-10-10).

69 S 101(2) of the Securities Services Act.

70 S 105(5) of the Securities Services Act.
} 
Markets Bill, the Financial Markets Bill 2012 and the Financial Markets Act, ${ }^{71}$ but nonetheless only the Financial Markets Bill states expressly that a court should take into account any award or penalty previously imposed against the offenders in respect of the same cause.

The Directorate of Market Abuse does not operate in isolation. It may further investigate any suspected market-abuse cases forwarded to it by the JSE's Surveillance Division. Put differently, the investigation team of the Directorate of Market Abuse undertakes full forensic investigations into alerts on the JSE's radar screen to detect market-abuse activities. ${ }^{73}$ Irrespective of this, the Securities Services Act does not clearly provide whether the JSE's Surveillance Division is statutorily obliged to report incidences of market abuse to the Directorate of Market Abuse. This flaw was not addressed in the Financial Markets Bill; the Financial Markets Bill 2012 and the Financial Markets Act. ${ }^{74}$

Finally, the Directorate of Market Abuse may, on behalf of the Financial Services Board, publish a list of market-abuse cases under investigation and proposed action, if any, in the press after every one of its meetings. ${ }^{75}$ Thus, the scope of the mandate and functions of the Directorate of Market Abuse is considerably wider because it deals with all the forms of market abuse as proscribed in the Securities Services Act. Importantly, this situation is also continued under the Financial Markets Bill; the Financial Markets Bill 2012 and the Financial Markets Act. ${ }^{76}$

\section{The role of the Enforcement Committee}

The Enforcement Committee is established as another committee of the Financial Services Board that administrates and adjudicates on all the forms of market abuse referred to it by the Directorate of Market Abuse or the Registrar of Securities Services. ${ }^{77}$ The Financial Services Board extended the jurisdiction of the Enforcement Committee to all the industries it regulates under the Securities Services $\mathrm{Act}^{78}$ by the insertion of some of its

71 Clause 92 read with clauses 86 and 87 of the Financial Markets Bill; clause 87 read with clause 84 of the Financial Markets Bill 2012; and s 85 read with s 82 of the Financial Markets Act.

72 Clause 89 of the Financial Markets Bill.

73 Loubser 2 October 2006 Insider Trading Booklet final draft 200626 http://www. jse.co.za/public/insider/JSEbooklet.pdf (accessed 2008-10-10).

74 See the functions of the Directorate of Market Abuse as contained in clause 92 of the Financial Markets Bill; clause 87 of the Financial Markets Bill 2012; and s 85 of the Financial Markets Act.

75 Generally see Loubser 2 October 2006 Insider Trading Booklet final draft 200626 http://www.jse.co.za/public/insider/JSEbooklet.pdf (accessed 2008-10-10). Nineteen cases of insider trading were investigated by the DMA between November 2004 and April 2007. Three of these cases were abandoned (closed) and the remaining sixteen are still pending. See the Directorate of Market Abuse Report Media Release http://www.fsb.co.za (accessed 2008-06-13).

76 Clause 92 read with clauses $86 ; 87$ and 88 of the Financial Markets Bill; clause 87 read with clause 84 of the Financial Markets Bill 2012; and s 85 read with s 82 of the Financial Markets Act.

77 See s 94(e) and s 97 of the Securities Services Act; and see further Luiz "Market Abuse and the Enforcement Committee" 2011 SA Merc LJ 151 155-172.

$78 \mathrm{~S} 97$ to $\mathrm{S} 105$ of the Securities Services Act. 
relevant provisions in the Financial Institutions (Protection of Funds) Act 28 of 2001 as amended. ${ }^{79}$ In relation to this, the powers of the Registrar of Securities Services to refer matters to the Enforcement Committee have been reintroduced in the Financial Markets Bill, the Financial Markets Bill 2012 \& the Financial Markets Act. ${ }^{80}$

Moreover, the Enforcement Committee is made up of members who are appointed by the Financial Services Board. ${ }^{81}$ At least two of the appointed members must be legally qualified. ${ }^{82}$ The Enforcement Committee may further appoint additional members with appropriate knowledge and experience. ${ }^{83}$ Any of the members who has investigated or who has an interest in a matter cannot take part in a decision of the Enforcement Committee on that matter. ${ }^{84}$ The Financial Services Board may yet again appoint, from the members, a chairperson and deputy chairperson of the Enforcement Committee. ${ }^{85}$ Conspicuously, the Financial Markets Bill, the Financial Markets Bill 2012 and the Financial Markets Act do not have a specific provision that deals with the general composition of the Enforcement Committee. $^{86}$

The functions of the Enforcement Committee include powers to deal with any matter referred to it in accordance with the relevant provisions of the Securities Services Act. ${ }^{87}$ The Enforcement Committee is also required to submit to the Financial Services Board an annual report on the activities of the Enforcement Committee during the preceding calendar year within the period and containing the information specified by the Financial Services Board. ${ }^{88}$ However, the Financial Markets Bill, the Financial Markets Bill 2012 and the Financial Markets Act do not provide any specific functions of the Enforcement Committee in detail. ${ }^{89}$

Referral of any matter relating to market abuse to the Enforcement Committee may be instituted in terms of the relevant provisions of either the Securities Services Act ${ }^{90}$ or the Protection of Funds Act. ${ }^{91}$ The referral of any

79 Hereinafter "the Protection of Funds Act"; see s 6B to s 6I of the Protection of Funds Act. Also see Van Deventer "Harnessing Administrative Law in Encouraging Compliance" 2009 FSB Bulletin 3 3-4.

80 Clause 105 of the Financial Markets Bill; clause 101 of the Financial Markets Bill 2012; and s 99 of the Financial Markets Act.

$81 \mathrm{~S} 98$ of the Securities Services Act.

$82 \mathrm{~S} 98(1)$ of the Securities Services Act.

$83 \mathrm{~S} 98(2)$ of the Securities Services Act.

$84 \mathrm{~S}$ 98(3) of the Securities Services Act.

85 S 98(4) of the Securities Services Act.

86 See clause 105 and the relevant clauses under Chapter X entitled "Market Abuse" of the Financial Markets Bill; clause 101 and the relevant clauses under Chapter X entitled "Market Abuse" of the Financial Markets Bill 2012; and s 99 and the relevant provisions under Chapter X entitled "Market Abuse" of the Financial Markets Act.

87 S 99; and S 102 to s 105 of the Securities Services Act.

$88 \mathrm{~S}$ 99(2) of the Securities Services Act.

89 See clause 105 and the relevant clauses under Chapter X entitled "Market Abuse" in the Financial Markets Bill; clause 101 and the relevant clauses under Chapter X entitled "Market Abuse" of the Financial Markets Bill 2012; and s 99 and the relevant provisions under Chapter X entitled "Market Abuse" of the Financial Markets Act.

$90 \mathrm{~S} 94(\mathrm{e})$ of the Securities Services Act.

91 See further $s$ 6A read with $s 6 B$ to $s$ l of the Protection of Funds Act. 
matter to the Enforcement Committee in terms of the Securities Services Act is usually done by the Directorate of Market Abuse. ${ }^{92}$ Precisely, the referral of any matter in terms of the Securities Services Act must be instituted in the manner proscribed in its relevant provisions. ${ }^{93}$ More to the point, the referral of a matter to the Enforcement Committee in terms of the Securities Services Act may be withdrawn by the Registrar of Securities Services or the Directorate of Market Abuse. ${ }^{94}$ Likewise, the referral of any matter to the Enforcement Committee in terms of the Protection of Funds Act may be done by the Registrar of Securities Services or the Directorate of Market Abuse. ${ }^{95}$ Nonetheless, cases in which the Registrar of Securities Services has authority to impose penalties cannot be referred to the Enforcement Committee. ${ }^{96}$ Moreover, as earlier stated, the Registrar of Securities Services also has powers to refer matters to the Enforcement Committee in terms of the Financial Markets Bill, the Financial Markets Bill 2012 and the Financial Markets Act. ${ }^{97}$

Each matter referred in terms of the Securities Services Act will be assigned to a panel consisting of the chairperson or deputy chairperson and at least two other members of the Enforcement Committee. ${ }^{98}$ This panel determines its own procedure for the performance of its functions and its proceedings are open to the public. ${ }^{99}$ The decision of the panel must be given in writing with reasons, and the decision of the majority of the members of the panel is regarded as the decision of the Enforcement Committee. ${ }^{100}$

Where any matter relating to market abuse or other related violations is referred to the Enforcement Committee as contemplated in the Protection of Funds Act, the applicant must give a notice with details of the alleged contravention, proposed administrative sanction and an affidavit setting out the facts and documents supporting such notice. ${ }^{101}$ The applicant is further required to deliver a copy of the notice and affidavit to the respondent's residential address, registered office or principal place of business and to give the respondent an opportunity to submit an answering affidavit within 30 days of delivery of such notice and affidavit to the respondent. ${ }^{102}$ Thereafter, the respondent is required in any matter relating to market abuse to file a copy of the answering affidavit with the Enforcement Committee and the applicant. This affidavit must state which allegations the respondent admits or denies, as well as the respondent's version of facts. The applicant must deliver an affidavit in response in the manner stipulated in the Protection of

\footnotetext{
S 94(e) of the Securities Services Act.

S 102 of the Securities Services Act read with s 94(e) of the same Act.

$S$ 101(1) of the Securities Services Act.

$\mathrm{S} 6 \mathrm{~A}(1)$ and (2) of the Protection of Funds Act.

Van Deventer 2009 FSB Bulletin 3.

Clause 105 of the Financial Markets Bill; clause 101 of the Financial Markets Bill 2012; and s 99 of the Financial Markets Act.

98 S 100(1) of the Securities Services Act read with s 94(e) of the same Act.

99 S 100(2) and (3) of the Securities Services Act.

$100 \mathrm{~S} 100(4)$ and (5) of the Securities Services Act; and also see s 6D(4) of the Protection of Funds Act.

$101 \mathrm{~S} 6 \mathrm{~B}(1)$ and (2) of the Protection of Funds Act read further with s $6 \mathrm{~A}$ of the same Act.

$102 \mathrm{~S} 6 \mathrm{~B}(2)$ of the Protection of Funds Act.
} 
Funds $\mathrm{Act}^{103}$ within 30 days of delivery to the applicant of the respondent's affidavit. ${ }^{104}$ No further affidavits may be filled without permission of the Enforcement Committee. ${ }^{105}$ Nevertheless, the applicant may, after prior notice to the Enforcement Committee and the respondent, withdraw the referral of any matter involving market abuse, or enter into a written settlement agreement with the respondent during or after the proceedings of the Enforcement Committee. ${ }^{106}$

The hearing of any matter by the Enforcement Committee gives all the parties involved an opportunity to argue their case. ${ }^{107}$ In other words, the Enforcement Committee may order the parties involved or any other person to be examined and cross-examined so as to determine whether any market-abuse offence was committed. ${ }^{108}$ The Enforcement Committee may therefore impose administrative sanctions such as a penalty for punitive purposes by ordering the respondent (offender) to pay a sum of money to the Financial Services Board and a compensatory penalty by ordering the respondent (offender) to pay any affected person an amount of money determined by the Enforcement Committee for the damage or patrimonial loss suffered. ${ }^{109}$ The Enforcement Committee may further impose a compensatory penalty by ordering the respondent who engaged in insidertrading practices to pay the Financial Services Board an amount of money calculated in accordance with relevant provisions of the Securities Services Act. ${ }^{110}$ This compensatory penalty is usually paid by the insider-trading offenders and distributed to the affected persons by the Financial Services Board. Additionally, the Enforcement Committee may impose unlimited administrative penalties on any respondent who admits that he contravened the market-abuse provisions or when it determines that he actually contravened such provisions. ${ }^{11}$

Furthermore, the Enforcement Committee may impose compensatory orders on the market-abuse offenders in cases where there is a link between the unlawful conduct and calculable damages suffered by the affected party or the applicant. ${ }^{112}$ The Enforcement Committee may also impose cost orders on the market-abuse offenders for the investigation and preparation costs of the Financial Services Board. ${ }^{113}$ The Enforcement Committee may yet again order such offenders to pay the remuneration costs of its panel members. ${ }^{114}$ Any order made by the Enforcement Committee has legal force as if it were made by the High Court and may be enforced by the Financial Services Board in cases of non-payment by lodging a certified copy of the

$\mathrm{S} 6 \mathrm{~B}(2)(\mathrm{a})$ of the Protection of Funds Act.

$\mathrm{S} 6 \mathrm{~B}(4)$ of the Protection of Funds Act.

$\mathrm{S} 6 \mathrm{~B}(5)$ of the Protection of Funds Act.

$\mathrm{S} 6 \mathrm{~B}(6)$ and (7) of the Protection of Funds Act.

$\mathrm{S} 6 \mathrm{C}(1)$ and (2) of the Protection of Funds Act.

$\mathrm{S} 6 \mathrm{C}(3)$ to (5) of the Protection of Funds Act.

$\mathrm{S} 6 \mathrm{D}(2)$ of the Protection of Funds Act.

10 S 77(1); (2); (3) or (4) of the Securities Services Act.

111 S 103 and S 104 of the Securities Services Act; and also see S 6D of the Protection of Funds Act.

112 Van Deventer 2009 FSB Bulletin 3-4.

113 Ibid.

114 S $6 D(5)$ of the Protection of Funds Act; and see further s 105 of the Securities Services Act. 
order with the High Court or any competent court. ${ }^{115}$ Any order or sanction imposed on the market-abuse offenders by the Enforcement Committee must be made public. ${ }^{116}$ No member or employee of the Enforcement Committee and the Financial Services Board is allowed to disclose any information acquired in the performance of the functions of the Enforcement Committee and which relates to its decision unless such disclosure is done in accordance with the relevant provisions of the Securities Services Act. ${ }^{11}$ Nevertheless, no identical provision is found in the Financial Markets Bill, the Financial Markets Bill 2012 and the Financial Markets Act. ${ }^{118}$

When determining an appropriate administrative sanction, the Enforcement Committee may give regard to other factors such as the nature, duration, seriousness and extent of the contravention; ${ }^{119}$ any loss or damage suffered; $; 20$ the extent of the profit derived or loss avoided by the respondent; $;{ }^{121}$ the effect of the unlawful conduct on the relevant sector of the financial services industry; ${ }^{122}$ previous penalties or compensation paid on the same set of facts; ${ }^{123}$ the degree to which the respondent co-operated with the applicant and the Enforcement Committee, ${ }^{124}$ any mitigating factors submitted by the respondent that the Enforcement Committee considers relevant ${ }^{125}$ and the deterrent effect of the administrative sanction. ${ }^{126}$

A respondent or any person not happy with the market-abuse sanctions or any order made by the Enforcement Committee may appeal to the High Court. ${ }^{127}$ In light of this, the appellant does not need to apply to the Enforcement Committee for the leave to appeal. ${ }^{128}$ Moreover, the launching of the appeal proceedings does not suspend the operation or execution of a decision made by the panel of the Enforcement Committee. ${ }^{129}$ The appellant may still apply to the chairperson of the Enforcement Committee for such suspension.

The Enforcement Committee's market-abuse proceedings do not affect any person's right to seek a legal redress in other appropriate forums. ${ }^{131}$ It is therefore possible for a respondent to be penalized by the Enforcement Committee and also to be sued by the affected person in the civil courts.

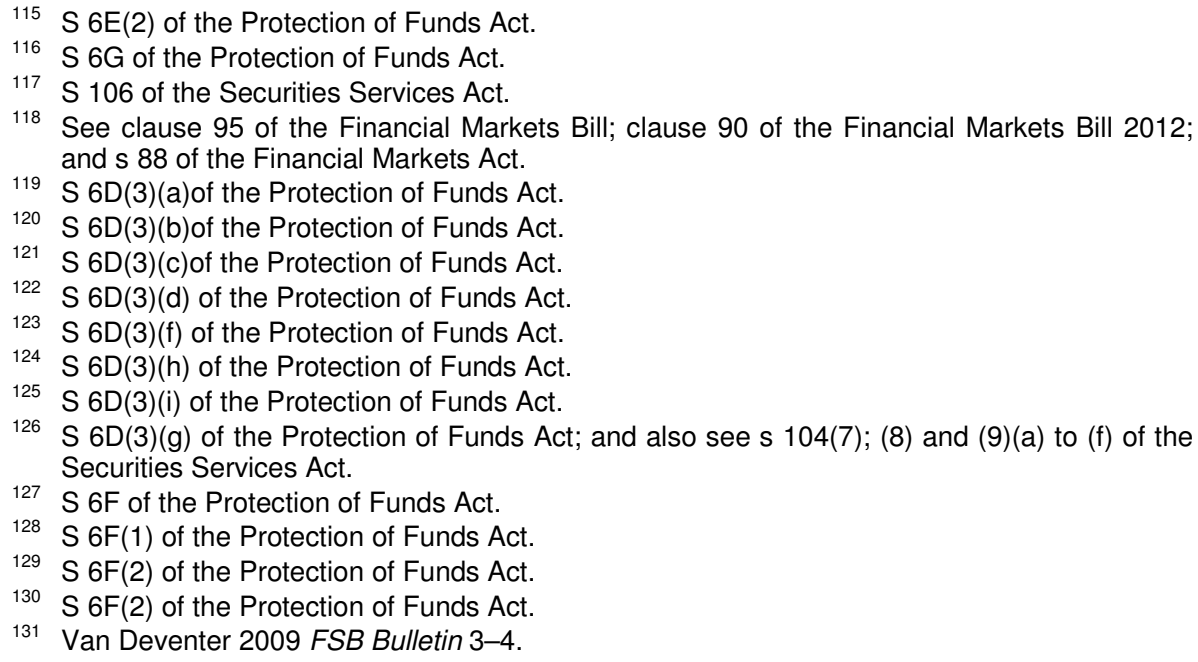


Seemingly, the administrative sanctions imposed by the Enforcement Committee against the market-abuse offenders do not limit the possibility of further criminal prosecution or other appropriate disciplinary proceedings to be effected against such offenders. ${ }^{132}$ This does not amount to double jeopardy as the latter court or tribunal is required to take into account any previous administrative sanctions imposed by the Enforcement Committee. ${ }^{133}$

Lastly, the Enforcement Committee may utilize the administrative sanctions recovered from the market-abuse offenders for the purposes of consumer education and the protection of the public by paying the fine into a trust fund as provided in the Securities Services Act. ${ }^{1{ }^{14}}$ Regardless of this, the authors submit that the mere fact that the Enforcement Committee may institute only appropriate proceedings against the market-abuse offenders on a referral basis, ${ }^{135}$ and where no compensation was paid by such offenders in respect of the same facts, ${ }^{136}$ it could, if not properly managed, have the effect of restricting and impeding the execution of its functions. ${ }^{13}$ Moreover, unlike the position under the Securities Services Act and the Protection of Funds Act as indicated above, the Financial Markets Bill, the Financial Markets Bill 2012 and the Financial Markets Act do not stipulate any specific procedure that may be followed in respect of any referral of market-abuse matters to the Enforcement Committee.

\section{Analysis and recommendations}

The success of any piece of legislation in any country is usually determined by the implementation of its provisions. It is against this background that a close examination of the relevant provisions of the Securities Services Act and other related legislation was undertaken to investigate whether they had been implemented to curb market-abuse practices in South Africa. Consequently, the duties of the enforcement authorities that primarily deal with the investigation and prevention of market-abuse activity in South Africa, namely, the Financial Services Board, the Directorate of Market Abuse and the Enforcement Committee, will be briefly and carefully analysed below.

As earlier discussed, ${ }^{139}$ the Financial Services Board still has various challenges with regard to the monitoring and enforcement of the market

132 Ibid.

$133 \mathrm{~S} 6 \mathrm{l}$ of the Protection of Funds Act. Also see Van Deventer 2009 FSB Bulletin 3-4.

$134 \mathrm{~S} 77(7),(8)$ and (9) of the Securities Services Act. See further $\mathrm{S} 6 \mathrm{H}$ of the Protection of Funds Act.

$135 \mathrm{~S} 94(\mathrm{e})$ of the Securities Services Act; and 6A of the Protection of Funds Act.

$136 \mathrm{~S} 6 \mathrm{D}(3)(\mathrm{f})$ of the Protection of Funds Act.

137 Cassim "An Analysis of Market Manipulation under the Securities Services Act 36 of 2004 (Part 2)" 2008 SA Merc LJ 177 191-193.

138 Clause 105 of the Financial Markets Bill; clause 101 of the Financial Markets Bill 2012; and s 99 of the Financial Markets Act.

139 See par 21 above. 
abuse provisions in South Africa. ${ }^{140}$ The fact that the Financial Services Board has limited prosecutorial powers in that it may prosecute only criminal cases of market abuse if the Director of Public Prosecutions or a competent court has declined to prosecute them is a case in point. ${ }^{141}$ Given the existing courts' backlog challenges in South Africa, it is submitted that not all premises and persons will be promptly searched, interrogated or prosecuted by the Financial Services Board and/or the competent courts. Thus, even though the availability of adequate resources could be problematic, more courts or additional special commercial courts or tribunals should be established to adjudicate on market-abuse cases in South Africa. In light of this, the Financial Services Board should further consider having more offices and other divisions of its departments in different regions of South Africa in order to increase awareness ${ }^{142}$ and to enhance the implementation of its functions. It is further submitted that, although it might be cheaper for the victims of market abuse to claim their damages through the Financial Services Board, this might have, on the other hand, also deterred other affected persons from claiming their damages through the Financial Services Board because of fears that such a strategy would be too bureaucratic. ${ }^{143}$ Moreover, no cross-border market-abuse cases have so far been timeously settled successfully with the Financial Services Board, probably as a result of several factors which include, among others, the unavailability of the relevant resources. ${ }^{144}$ This could have been further aggravated by the fact that the Financial Services Board does not have its own surveillance equipment in place to detect any suspected market-abuse practices timeously and to provide the details of the beneficial owners of securities held in nominee accounts in South Africa or elsewhere.

Notwithstanding its commendable efforts to curb market abuse in South Africa, the Directorate of Market Abuse is still to achieve more success in relation to the execution of its market-abuse duties. ${ }^{145}$ For example, it has restricted authority and does not perform any of its duties without confirmation from the Financial Services Board and the competent courts. ${ }^{146}$ This clearly suggests that the Directorate of Market Abuse does not have the power of its own to make market-abuse rules and this could be affecting the execution of its duties negatively. In relation to this, one could have expected that the Directorate of Market Abuse (which is a committee of the Financial

140 See s 82 of the Securities Services Act; clause 91 of the Financial Markets Bill; clause 86 of the Financial Markets Bill 2012; and s 84 of the Financial Markets Act which outlines some of the duties of the Financial Services Board.

141 See s 82(9) of the Securities Services Act; clause 91(9) of the Financial Markets Bill; clause 86(10) of the Financial Markets Bill 2012; and s 84(10) of the Financial Markets Act.

142 Notwithstanding the fact that the Financial Services Board is entitled to publish notices in relation to market-abuse offences in terms of $s$ 82(5) of the Securities Services Act to increase awareness, it has not successfully implemented this provision particularly owing to the inadequate availability of resources. Additionally, it remains to be seen whether a similar provision which is contained in clause 91(5) of the Financial Markets Bill; clause 86(6) of the Financial Markets Bill 2012; and S 84(6) of the Financial Markets Act will be utilized successfully by the Financial Services Board to increase awareness.

143 Generally see related comments in par 21 above.

144 Ibid.

145 See par 22 above.

146 S 78; s 83 of the Securities Services Act; clauses 92 \& 88 of the Financial Markets Bill; clause 87 of the Financial Markets Bill 2012; and s 85 of the Financial Markets Act. 
Services Board) will be allowed to execute its duties without prior confirmation from the Financial Services Board in order to curb potential bureaucracy. Moreover, the Directorate of Market Abuse does not have its own surveillance systems in place to detect, investigate and prevent the occurrence of market-abuse practices in the South African financial markets. Specifically, as stated earlier, ${ }^{147}$ the Directorate of Market Abuse depends on the JSE's Surveillance Division for its market-abuse investigations. ${ }^{148}$ Despite submissions by other commentators like Rob Barrow (the former chief executive officer of the Financial Services Board) ${ }^{149}$ that the Directorate of Market Abuse now has sufficient measures in place and competent personnel to improve the enforcement of the market-abuse provisions in South Africa, a few convictions and settlements attained to date may suggest otherwise. ${ }^{150}$ In relation to this, it is submitted that the Financial Services Board and/or the Directorate of Market Abuse should have its own surveillance equipment in place to detect any suspected market-abuse practices in South Africa and elsewhere timeously.

Although the Enforcement Committee is empowered as a committee of the Financial Services Board which administers the administrative sanctions for market abuse in South Africa, it may only institute administrative or civil proceedings in a court of law against the offenders on a referral basis, ${ }^{151}$ and where no compensation was paid by the defendant as provided under the Securities Services Act. ${ }^{152}$ This referral procedure might have weakened the enforcement functions of the Enforcement Committee and could, if not properly managed, continue to have the affect of restricting or impeding the implementation of the administrative sanctions for market abuse in South Africa. ${ }^{153}$ Besides, in spite of the fact that the Enforcement Committee may impose unlimited administrative penalties against the market-abuse offenders, not many cases of market abuse have been settled with the Enforcement Committee to date. ${ }^{154}$

\section{CONCLUDING REMARKS}

This article has analysed the role and effectiveness of three key role-players that primarily deals with the investigation, prevention and enforcement of the market-abuse prohibition in South Africa, namely, the Financial Services Board, the Directorate of Market Abuse and the Enforcement Committee. Additionally, an overview analysis of each of these role-players as well as

147 See generally par 22 above.

148 Loubser 2 October 2006 Insider Trading Booklet final draft 2006 26-27 http://www. jse.co.za/public/insider/JSEbooklet.pdf (accessed 2008-10-10).

149 Barrow 28 July 2004 Business Report (2004-07-28); and also see generally par 21 above.

150 Chanetsa "Insider Trading is Notoriously Hard to Prosecute" 26 April 2004 Business Report; and also see generally par 22 above.

151 S 101 of the Securities Services Act; also see clause 105 of the Financial Markets Bill; clause 101 of the Financial Markets Bill 2012; and s 99 of the Financial Markets Act.

152 S 77; and s 105(5) of the Securities Services Act.

153 See s 101; s 102 of the Securities Services Act, read with clause 105 of the Financial Markets Bill; clause 101 of the Financial Markets Bill 2012; and s 99 of the Financial Markets Act.

154 See generally par 23 above. 
their distinct functions in the investigation and prevention of market-abuse practices in South Africa was done to examine whether they are effectively enforcing the market-abuse provisions to combat insider trading and market manipulation in the South African financial markets. In relation to this, it was noted that significant progress has been made in the enforcement of the market-abuse prohibition in this country. For example, in an attempt to establish a good enforcement framework, the Directorate of Market Abuse was established as an investigatory arm of the Financial Services Board, while the Enforcement Committee was empowered to hear cases of market abuse and to impose unlimited administrative sanctions against anyone who violates the market-abuse provisions in South Africa. With regard to the detection of market-abuse activities, the Financial Services Board depends mainly on the JSE's Surveillance Division.

Irrespective of this, various shortcomings are still found in the enforcement of the market-abuse provisions in South Africa. ${ }^{155}$ Notably, the criminal penalties imposed against market-abuse offenders are still very little for deterrence purposes. ${ }^{156}$ Furthermore, the establishment of additional structures such as the Enforcement Committee to hear market-abuse cases on a referral basis, and the introduction of administrative sanctions has not been able to encourage all persons to comply with the market-abuse prohibition in South Africa. ${ }^{157}$ In relation to this, it was stated that the aforesaid referral procedure might have weakened the enforcement functions of the Enforcement Committee and could, if not properly managed, continue to have the affect of restricting or impeding the implementation of the administrative sanctions for market abuse in South Africa. ${ }^{158}$ It was also indicated that the Directorate of Market Abuse does not have the power of its own to make market-abuse rules and this could be affecting the execution of its duties negatively. ${ }^{159}$ In relation to this, it was suggested that the Directorate of Market Abuse (which is a committee of the Financial Services Board) should be allowed to execute its duties without prior confirmation from the Financial Services Board in order to curb potential bureaucracy. ${ }^{160}$ It was also suggested that the Directorate of Market Abuse should have its own surveillance systems in place to detect, investigate and prevent the occurrence of market-abuse practices in the South African financial markets. ${ }^{16}$

Moreover, in civil proceedings, the right to claim compensation is given exclusively to the Financial Services Board and no provision is made for the prejudiced persons to claim such compensation directly (a private right of action) from the perpetrators of market abuse. ${ }^{162}$ This could be too rigid and bureaucratic and may, if not carefully enforced, lead to the failure, on the part of the Financial Services Board, to compensate all the affected persons

155 See the analysis in par 24 above.

156 S 115(a) of the Securities Services Act; clause 115(a) of the Financial Markets Bill; clause 111(a) of the Financial Markets Bill 2012; and s 109(a) of the Financial Markets Act.

157 See the analysis in par 23 and 24 above.

158 See the analysis in par 24 above.

159 Ibid.

160 Ibid.

161 See related comments in par 24 above.

162 S 82(2)(c) of the Securities Services Act. 
speedily. ${ }^{163}$ Incongruously, the same weakness is replicated in the Financial Markets Bill, the Financial Markets Bill 2012 and the Financial Markets Act. ${ }^{164}$ Additionally, it was submitted that the failure of the Financial Services Board to have its own surveillance equipment that timeously detects any suspected market-abuse practices and/or provides the details of the beneficial owners of securities held in nominee accounts in South Africa or elsewhere could be negatively affecting its combating of cross-border market-abuse cases. ${ }^{165}$ It was further suggested that the Financial Services Board should consider having more offices and other divisions of its departments in different regions of South Africa in order to increase awareness and to enhance the implementation of its functions. ${ }^{166}$ Given this background, it is hoped that the academics will conduct more legal research on the functions as well as the challenges of the aforesaid role-players in order to increase awareness on the part of the general public, policy-makers and other relevant stakeholders and to recommend possible solutions that could be employed to enhance the enforcement of the market-abuse ban in South Africa.

163 See par 21 and 24 above.

164 Clause $91(2)(d)$ of the Financial Markets Bill; clause 86(2)(d) of the Financial Markets Bill 2012; and s 84(2)(d) of the Financial Markets Act.

165 See the analysis in par 24 above.

166 Ibid. 